USDA

United States Department of Agriculture

Agricultural Marketing Service

September 2009

\title{
Opening a
} Farmers Market on Federal Property:

A Guide for Market Operators and Building Managers

A joint publication by GSA and USDA 


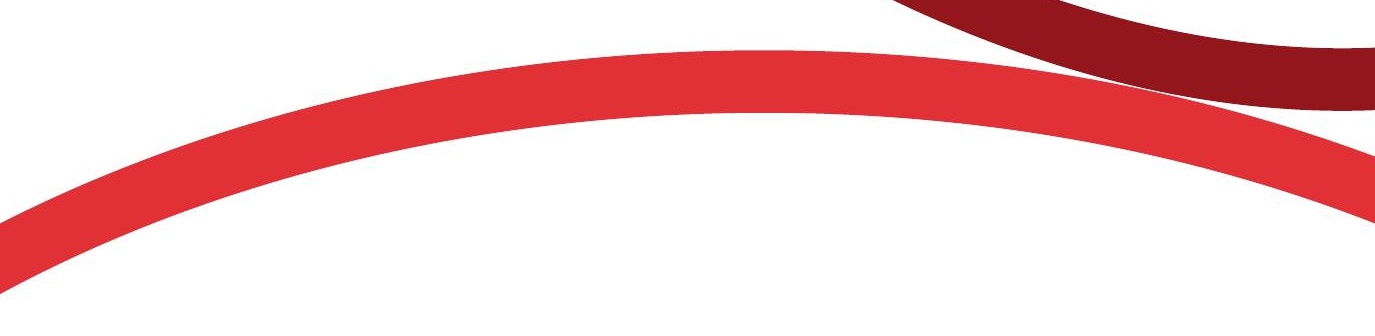

\section{Preferred Citation}

Beach, Karen, Frank Giblin, and Velma Lakins. Opening a Farmers Market on Federal Property:A Guide for Market Operators and Building Managers. U.S. Department of Agriculture, Agricultural Marketing Service, September 2009. Web. <http://dx.doi.org//0.9752/MS036.09-2009>

The U.S. Department of Agriculture (USDA) prohibits discrimination in all its programs and activities on the basis of race, color, national origin, age, disability, and where applicable, sex, marital status, familial status, parental status, religion, sexual orientation, genetic information, political beliefs, reprisal, or because all or part of an individual's income is derived from any public assistance program (not all prohibited bases apply to all programs). Persons with disabilities who require alternative means for communication of program information (Braille, large print, audiotape, etc.) should contact USDA's TARGET Center at (202) 720-2600 (voice and TDD). To file a complaint of discrimination, write to USDA, Director, Office of Civil Rights, 1400 Independence Avenue, S.W.,Washington, D.C. 20250-94I0, or call (800) 795-3272 (voice) or (202) 720-6382 (TDD). USDA is an equal opportunity provider and employer. 
United States

Department of

Agriculture

Agricultural

Marketing

Service

September 2009

\section{Opening a}

\section{Farmers Market}

on Federal

Property:

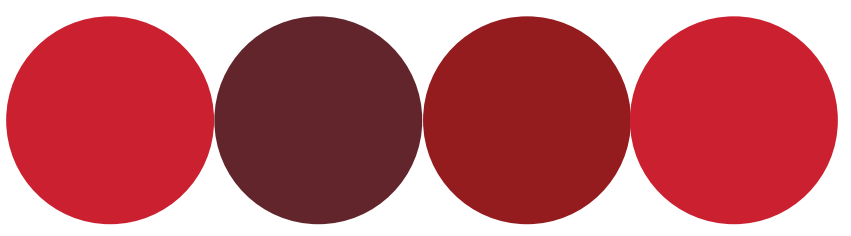

\section{A Guide for}

Market Operators

and Building

Managers

A joint publication by:

Karen Beach and Frank Giblin

Urban Development/

Good Neighbor Program

U.S. General Services Administration

Velma Lakins

Marketing Services Division

USDA, Agricultural Marketing Service 



\section{Opening a Farmers Market on Federal Property: A Guide for Market Operators and Building Managers}

Throughout the United States, the number of farmers markets continues to rise, their popularity spurred by consumers' growing demand for locally produced food. More than 4,900 farmers markets operate nationwide today-a jump from fewer than I,800 only I5 years ago. In addition to providing easier access to fresh food, studies show establishing a farmers market can revitalize a neighborhood, enhance social interaction, improve the local economy, and provide a supplemental source of farm income for many growers.

Moreover, because farmers markets increase the availability of fresh fruits and vegetables for consumers, they play an important role in the Government's mission to combat childhood obesity. The United States Department of Agriculture (USDA) has operated a farmers market at its Washington, D.C., headquarters since 1996. (For more information, see "Market Successes" at the end of this guide.) USDA also supports farmers markets through additional programs managed by several USDA agencies. The Agricultural Marketing Service (AMS), for example, awards grants, offers technical assistance, and helps with marketing and promotion.

AMS also worked with the General Services Administration (GSA), the agency that operates most Federal properties, to produce this guide on how market operators and building managers can establish and operate farmer markets on Federal properties. Because most Federal buildings are prominently positioned in central business districts, they're great places to open a farmers market, and sites may be available for use at minimal or no cost. Several farmers markets already are established on federally owned sites, and they're bringing a range of benefits to their building managers and market operators. 
Market operators: Your first step should be to meet with the manager of your local Federal building. If it's run by GSA, you can find contact information at www.gsa.gov. Another resource is the Urban Development/Good Neighbor program (www.gsa.gov/goodneighbor), which can provide information and help set up the initial meeting.

Building managers: Even though public use of Federal property might require heightened security and additional insurance, the markets themselves offer big returns for little effort or resources. Here are some points to keep in mind when considering opening a farmers market on your building site:

First, farmers markets may increase income for buildings. Well-used civic spaces that make a good impression may attract more tenants. If a building's public areas are perceived as lively, inviting, and efficiently used, its available office space will be in greater demand. Previously unproductive outdoor areas can be sites for concessions, activities, and events on days the market does not operate. Furthermore, markets may increase customer satisfaction. Both employees and visitors are drawn to active and attractive civic spaces in and around the building where they work or transact business. Attractive spaces boost productivity, help recruit and retain employees, and vastly improve the public image of both the tenant agencies and the Federal Government. In addition, an actively

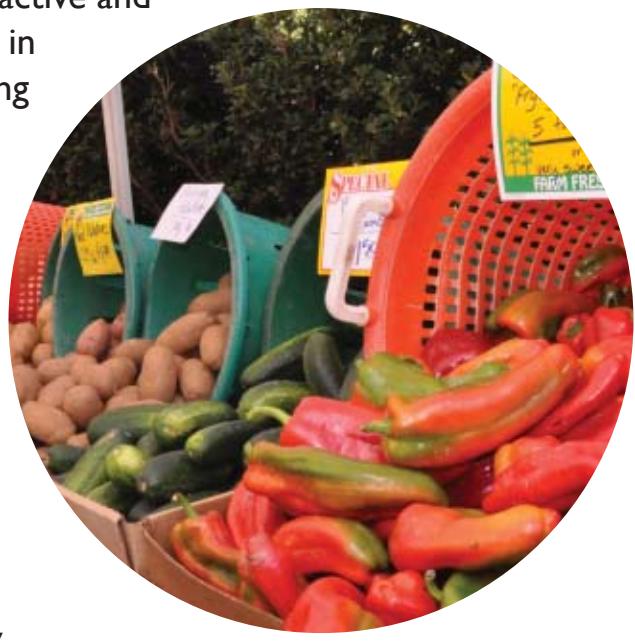
programmed civic space that is clean and welcoming feels much safer than an empty one. Finally, markets can support the missions and programs of tenant agencies. 


\section{Market Operations}

Each market and location will have specific requirements that building managers and market operators should discuss during the first stages of the partnership. In most cases, technical issues can be resolved through proactive, creative, and flexible planning. Here are some key topics to consider during the planning phase.

\section{Security}

Varying security requirements apply to each Federal property, and building managers should determine how normal market operations can best accommodate these needs. For example, in more secure locations, building managers may need to request, and market operators should be prepared to provide, vendor information for background checks prior to opening a market. In most cases, market operators and building managers should not encounter problems adhering to specific security protocols if these are identified and discussed ahead of time.

Vendor vehicles raise particular concerns with security professionals. Most vendors prefer easy access to their trucks during market days, but security guidelines at some Federal locations prohibit parking at the site. If the Federal property cannot accommodate trucks because of security regulations or lack of space, the building manager may be able to help vendors locate nearby parking for market days. If the area allows parking trucks on-site, locking them during market hours may suffice.

\section{Rent}

Most Federal properties offer spaces to markets rent-free, which is an attractive incentive for building managers to offer. However, if market operations incur other expenses for the Federal site, such as operating after business hours or hiring additional security personnel, markets would be responsible for covering them. These expenses should be estimated ahead of time as part of the permitting process. 


\section{Permits}

Building managers usually define the terms of the partnerships, and some market operators may be required to hold annual or tri-annual permits. Market operators interested in holding their markets on GSA properties should submit GSA Form 3453, Application/Permit for Use of Space in Public Buildings and Grounds, a one-page sheet that requires a name, contact information, a description of the activity, and other basic information. Sample permit documents are available through the GSA Urban Development/Good Neighbor program (www.gsa.gov/goodneighbor).

\section{Insurance}

Market operators typically must hold insurance policies for operations at other, non-Federal locations and should expect to do the same for markets at Federal facilities. Most Federal properties require market operators to have a general liability policy of at least $\$$ I million covering bodily injuries and accidents; individual vendors may also need to be insured.

\section{Utilities}

Some Federal properties are able to provide markets with access to utilities such as restrooms, water, and phone lines; also, vendors of meat, fish, or dairy products may need electrical outlets. You should discuss ahead of time what is available and who is responsible if these incur costs-building managers, market operators, or vendors. The building may be able to provide access to the restrooms in a Federal facility, but market operators should arrange in advance for any necessary security IDs for vendors, their employees, and market management personnel. It may be possible to expedite the process by providing a list of names to the security desk. Also, public restrooms nearby should be identified if the Federal building prohibits access to non-employees. 


\section{Maintenance and Trash Removal}

Building managers should expect market operators to remove their own trash on market days, as is the practice at other farmers market sites. Most Federal properties, however, have janitorial staffs or maintenance contracts; thus, the responsibility for or costs of trash removal and site maintenance should be discussed.

\section{Customer Parking and Transit}

If the Federal property is accessible only by car, the market needs to identify parking locations for customers who do not work in the Federal building. Locating markets on Federal property with close proximity to transit stops or public parking alleviates this need.

\section{Frequency}

Market operators and building managers should work together on selecting optimum days and times for markets. Building managers can pinpoint when the greatest number of people pass or enter the building. If the property is in a commercial area, market hours during the morning or evening commutes and lunch times most likely will attract the most customers.

\section{Amenities}

Markets are more successful when they offer customers shade and seating. Therefore, it is important to discuss whether the building or the market may set up tables and chairs so building tenants and other customers can spend time in the market talking, eating, and relaxing.

\section{Ongoing Communication}

Even after agreements are signed and the market established, building managers and market operators should remain in communication. In-person contact on market days helps keep relationships friendly and open. 


\section{Wholesale Buying Options}

If there is a cafeteria in the building, it may be useful to investigate whether the food service provider is interested in purchasing food from the market, providing vendors a steady source of revenue.

\section{Market Promotions}

\section{Promotions}

Market operators typically are responsible for promotion, but building managers can also advertise through in-house newsletters or Intranet postings. Market operators should find out in advance, from facility managers, if the building allows flyers and posters in common areas.

\section{Events}

Markets attract more customers when they offer such events as cooking demonstrations or live music. Although building managers spread the word through advertising and other promotion, market operators should be responsible for the events themselves. Building managers should also talk with market operators and tenant agencies about showcasing their missions and programs.

\section{Signage}

Markets draw more customers with well-

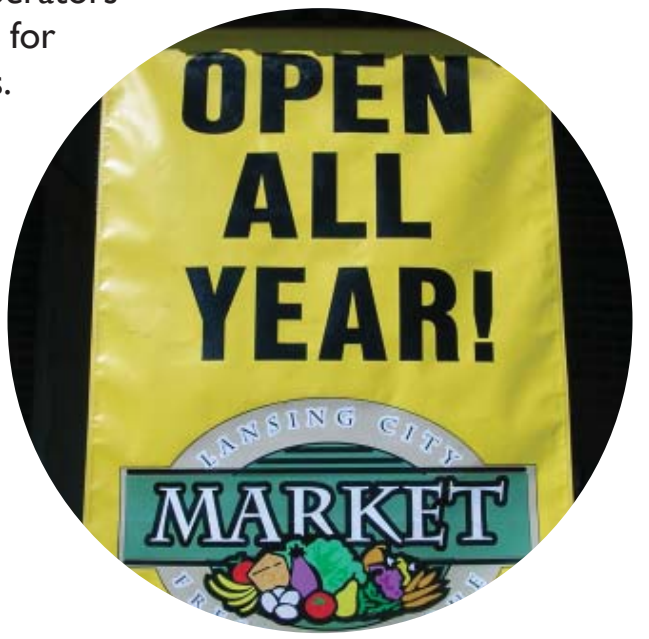
designed, well-placed signs. If the building has the space and you can hang a banner or sign, market operators should create these together with building managers. 


\section{Customers}

Unless the complex has a large number of tenants, the market may need to draw additional customers to supplement the Federal employee base. To attract the general public, the market should be located at a site where there is a lot of pedestrian

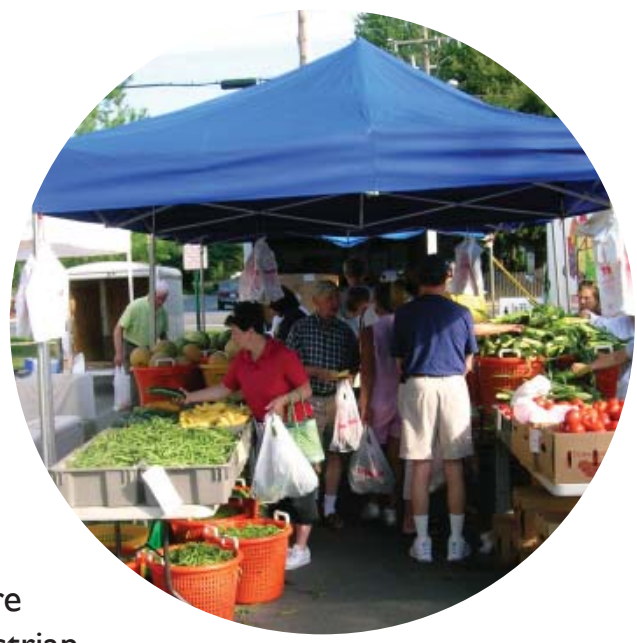
traffic, and signs should be placed where pedestrians are likely to see them.

\section{Sponsorships, Partners, and Fundraising}

Market operators and building managers should discuss restrictions on fundraising and promotion on Federal property, in case market sponsors and partners ask to display their logos or hold fundraising activities at the market.

After discussions on these issues are completed, building managers will then obtain permission from the appropriate authority at GSA. Because most concerns likely will focus on security and the physical space of the market, market operators should provide building managers the logistics and other details of the market, then work together to prepare a sketch of the proposed layout that shows where and how the market can best fit on the property. 


\section{Market Successes}

\section{USDA Building, Washington, DC}

The USDA farmers market, established in 1996, operates in a parking lot at its headquarters in Washington, DC, every Friday, June through October. Its prime location, near the National Mall, the Smithsonian museums, and other Government buildings helps the market attract more than 2,500 Federal employees, tourists, and community supporters each week during peak market season. As many as 14 vendors offer farm-fresh fruits and vegetables, baked goods, herbs and spices, flowers, and value-added items. Although vendors are permitted to park on-site adjacent to their booths, security requires their vehicles to be locked and valuables to be stored out of sight during market hours. AMS manages the market, and other USDA offices contribute to the market by providing the market operator and vendors with USDA tents, security, electricity, trash removal, and limited building access to the cafeteria and restrooms during market hours. Because the market's popularity has continued to grow, in fall 2008, USDA added a weekly indoor market during the winter months, housed in the building's cafeteria. The market has become an integral part of USDA's mission to encourage healthy meals, promote locally produced food, and develop effective direct marketing strategies for small farmers. For more information on the market, contact Velma Lakins, Agricultural Marketing Specialist with USDA-AMS at velma.lakins@ams.usda.gov. 


\section{Kluczynski Federal Building, Chicago, IL}

The Federal Plaza Farmers Market has been operating weekly, May through October, since 1992. Managed by the Mayor's Office of Special Events, the popular market features more than 30 vendors selling local farm products to 2,000-plus Federal workers and employees of nearby businesses. The market operator and building manager work closely together. Each market morning the building manager walks through the market and checks in with the market manager and vendors. Because the location has a high level of security, vendors' stalls must be approximately 100 feet away from the Federal building. Also, vendors are allowed to have their trucks on-site only while dropping off wares and again when they reload at the end of the market day. Throughout the market season, one of the Federal buildings on the plaza displays a banner advertising the market. Both the market operator and individual vendors are required to submit applications annually and must hold general liability policies.

\section{UN Plaza, San Francisco, CA}

Operating since 1981, the semi-weekly Heart of the City Certified Farmers Market serves both residents and employees in San Francisco's Tenderloin district. Originally established to create a safe, positive destination in an area of the city with high rates of crime and poverty, the market has grown from 14 farmers to more than 70 during peak season and attracts thousands of customers. The market is in a city plaza, directly in front of a vacant Federal building. Security requirements are minimal for such a high security location and, therefore, trucks are allowed on-site but must remain locked during market operations. In addition, market operators must leave a clear path to the front door of the Federal building sufficient to accommodate emergency vehicles. Building management reports the market connects them to the local community and has helped rejuvenate the area for residents and employees alike. 


\section{Republic Square, Austin, TX}

The Sustainable Food Center, in partnership with the city, opened the Austin Farmers Market in 2003 following 2 years' planning. During peak season, more than 60 vendors set up around a beautiful downtown park, across the street from the site of the future Austin Federal Courthouse. Even though the Federal building is not yet constructed, the market operator and building manager have been working closely together for over a year. A sign advertising the market already hangs on the fence that encompasses the building site, and when the building opens, the market will relocate some vendors to a public plaza in front of the courthouse.

\section{Communitywide Benefits}

\section{Gleaning}

In October 1996, the Bill Emerson Good Samaritan Food Donation Act to support "gleaning" and food recovery went into effect. The law encourages donating food and grocery products to nonprofit charitable organizations for distribution to those in need. An example is the USDA farmers market, which is free of charge to all participants, and asks market vendors to support the USDA gleaning/food recovery initiative, in lieu of fees. The commitment requires farmers and vendors at the close of each market day to donate surplus food and food products to a local nonprofit organization identified by the USDA. In recent years, the recipient of donations from the USDA Farmers Market has been the DC Central Kitchen.

Since 2003, the USDA has helped combat food insecurity and inaccessibility by donating thousands of pounds of fresh produce, baked goods, and value-added items from its weekly farmers market to DC Central Kitchen. Each day, DC Central Kitchen recovers more than one ton of food from restaurants, farms, and events; prepares and delivers meals to partner social service agencies; trains and employs homeless men and women for careers in the culinary industry; and intellectually engages volunteers. 


\section{Additional Resources}

Urban Policy Update: Reinvigorating Public Use of GSA Buildings - Public Buildings Cooperative Use Act of 1976

This Urban Policy Update is targeted to help GSA property managers, partner organizations, and the public work together to enliven Federal facilities by incorporating public use into the buildings' operations, and even into their designs. The Update provides background on GSA's abilities to accommodate public programming and "how-to" guidance on short- and long-term use. Included throughout are examples from around the country that describe successful uses of Federal facilities and points of contact for additional questions. The guide is available electronically on the GSA UD/GNWeb site, www.gsa.gov/goodneighbor.

\section{AMS Farmers Market Web site}

AMS's Marketing Services Division maintains an archive of farmers market resources, which incorporates a wide range of user-friendly information about market trends, statistics, promotional tools, and funding opportunities for market operators, planners, and other stakeholders. The archive also features a search engine that enables users to obtain basic facts about every farmers market located in the United States. For additional details, please visit the AMS Farmers Market and Local Food Marketing Web site at www.ams.usda.gov/ farmersmarkets.

\section{Acknowledgments}

The authors would like to acknowledge Steve Davies and Kelly Williams with the Project for Public Spaces for their assistance with the research and development of this report. 


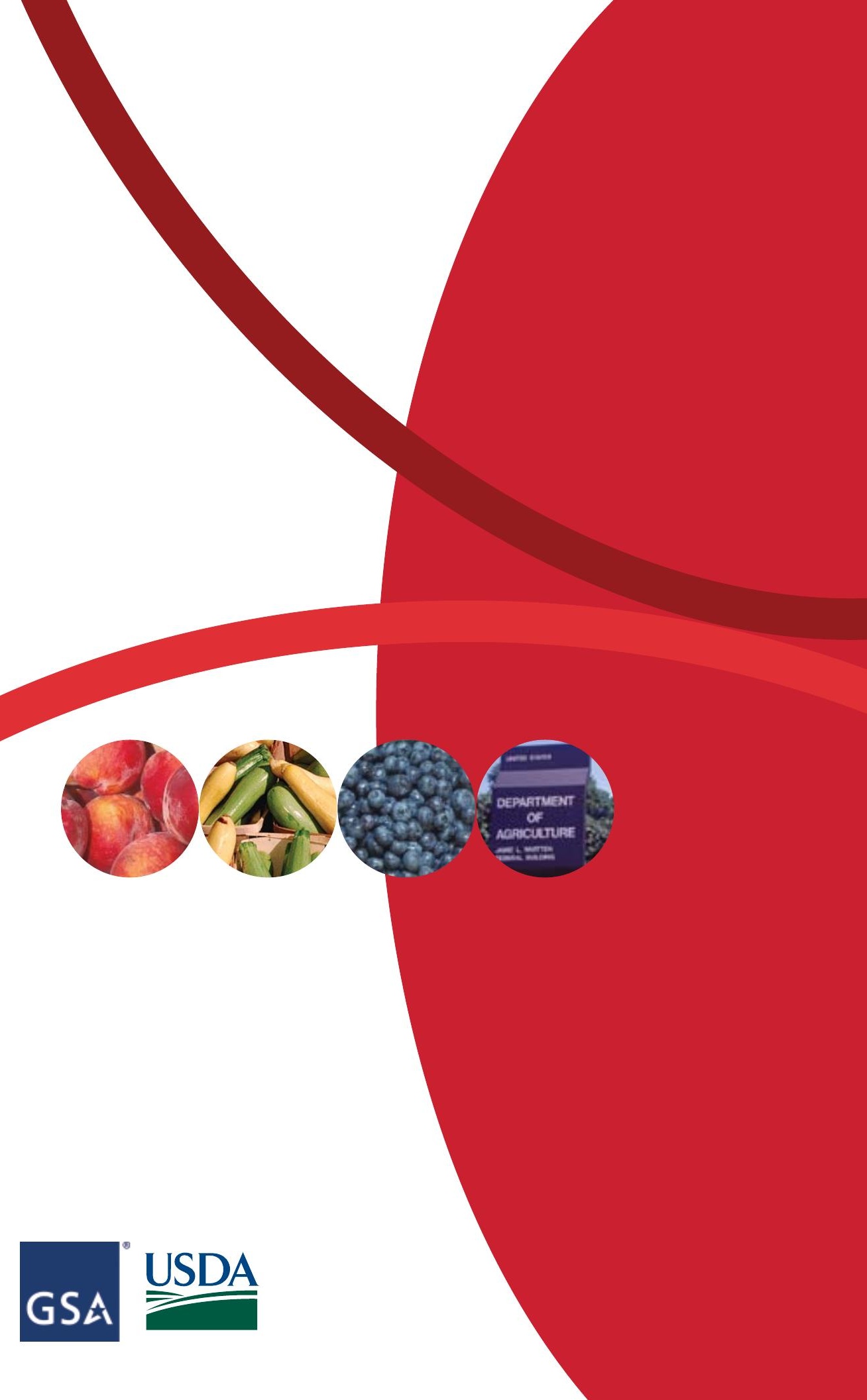

